\title{
Types of Interaction in Online Discussion Forums: A Case Study
}

\author{
Zuheir Khlaif \\ Department of Instructional Systems Technology, School of Education, Indiana University \\ 201 N. Rose Avenue, Bloomington, IN 47405, USA \\ Tel: 1-812-361-7920Ｅ-mail: zkhlaif@indiana.edu
}

Hamid Nadiruzzaman

Department of Instructional Systems Technology, School of Education, Indiana University 201 N. Rose Avenue, Bloomington, IN 47405, USA

Tel: 1-812-606-2874Ｅ-mail: hnadiruz@indiana.edu

Kyungbin Kwon (corresponding author)

Department of Instructional Systems Technology, School of Education, Indiana University

201 N. Rose Avenue, Bloomington, IN 47405, USA

Tel: 1-812-856-8460 E-mail: kwonkyu@indiana.edu

Received: March 23, 2017 Accepted: April 20, 2017 Published: April 21, 2017

doi:10.5296/jei.v3i1.10975 URL: https://doi.org/10.5296/jei.v3i1.10975

\begin{abstract}
The purpose of this paper is to identify the types of students' interaction, as well as their discussion patterns in an online course. The study took place in a large Midwestern University and 17 graduate students participated in the study. The primary data was obtained from students' discussion forum postings. The researchers used both qualitative and quantitative approaches to describe and analyze the types of discussion and interaction. The researchers developed a coding scheme based on theories and models. The findings of the study reveal that computer mediated communication (CMC) has a positive potential to increase interaction among students. Furthermore, the findings confirm the effectiveness of asynchronous online environment in supporting online learning community. Participants were
\end{abstract}


engaged in social interaction to build their knowledge. This study recommends two-way interaction for achieving sustainable discussion and promoting higher level of interaction.

Keywords: Online discussion, Online learning, Computer Mediated Communication

\section{Introduction}

The asynchronous online community creates the primary grounds of many current distance education courses and forms the basis for the creation of online learning communities that can overcome barriers of time and place (Gray \& Smyth, 2012). The 2015 Survey of Online Learning conducted by the Babson Survey Research Group reveals that more than one in every four students (about 28\%) now take at least one distance education course. In 2015, the growth rate of distance education courses was 3.9 percent over the previous year. Education leaders in the institutions report that "online learning is critical to their institution's long term strategy" which has grown from $48.8 \%$ in 2002 to $70.8 \%$ in 2015 in the United States (Allen \& Seaman, 2015).

Meaningful interaction in online learning plays a crucial and fundamental role in the knowledge acquisition and cognitive development process (Pena-Shaff \& Nicholls, 2004). Findings of previous studies reveal that student-student interaction in online discussion has been correlated with increased student satisfaction with course experience (Sher, 2009; Shu-Hui Hsieh \& Smith, 2008); students report more meaningful experience when they are able to interact with their peers. Similarly, Muller (2008) implied student engagement in online learning community to be an important factor in persistence of women in online degree programs.

Learning in the online environment is different from face-to-face. Students in face-to-face can interact with their peers and their instructor directly, whereas students in online environment can interact mainly through computer mediated communication (CMC) using tools, such as discussion boards, emails, chat, etc. (Choo, Kaur, Fook, \& Yong, 2014). In an online class, students are engaged in social and cognitive interaction by reading and responding to their instructor and peer's postings. Online learning tools could allow students to share ideas with their classmates by reading and reflecting on other students' postings, and comparing progress with others (Soon \& Fraser, 2011). Determining students' interaction in online learning is important for knowledge building purpose since the interaction influences the quality of distance learning (Chai \& Khine, 2006). Students tend to assess the quality of online learning based on their perceived interaction with the instructor and classmates in the distance education course (De Wever, Schellens, Valcke, \& Van Keer, 2006).

\subsection{The Problem Statement}

Interaction in online learning plays an essential role in the learning process among learners, instructors, and learning content (Wei, Peng, \& Chou, 2014). Many studies have been conducted since the emergence of CMC; these studies focus on the definition and description of interaction in online community. The relationship between participants, interaction and knowledge building in online learning requires further exploration (Balaji \& Chakrabarti, 2010; Pena-Shefa, 2004). Furthermore, Brook and Oliver (2003) state that identifying the 
factors that influence interaction in online community needs more data-driven approaches. There is a lack of research in terms of the quality of interaction and how it affects knowledge building (De Wever et al., 2006). Many studies report interaction in terms of frequency, not in terms of quality (Locar, Barret, \& Liu, 2014). Through our analysis framework, we tried to reveal the types of interactions and the types of discussion among students in the online learning community.

\subsection{The Purpose of the Study}

The purpose of the study is to identify the types of interaction in online discussion forums among graduate students in an online course in a large Midwest university. This study adopts a content analysis approach in order to analyze interaction types in an online learning community which may shed more light on online knowledge building process.

\section{Literature Review}

The adoption of CMC in higher education has far extended our understanding of how this medium should be used to endorse higher-order learning (Garrison, Anderson, \& Archer, 2001). Vygotysky (1978) mentioned that learning takes place through the interactions students have with their peers as they learn from each other. He emphasized the role of mutual engagement and co-construction of knowledge. These theories have advanced our understanding how learning occurs in an online learning community.

The basic principles of the learning theories support the learning needs of students (Chai \& Khine, 2006; Liu \& Tsai, 2008). Particularly relevant to online learning, the principles of constructivist learning theories include interaction and collaboration. These theories view learning as a process of interaction and participation of a community (Vygotsky, 1978). The constructivist principles describe how learning occurs in asynchronous discussions (Rodriguez, 2014; Swan, 2005; Yuan \& Kim, 2014) and serve as the primary approach to this study in exploring the discussion messages for evidence of learning. Network of interactions play a critical role in knowledge emergence and distribute it through different tools (Choo, Kaur, Fook, \& Yong, 2014). Therefore, social constructivist learning theory served as the theoretical framework of our research.

The CMC system has a critical role of online learning community for educational purposes. CMC has been widely used to support online peer discussion (Chai \& Shine, 2006; Choo et al., 2014; Liu \& Tsai, 2008). It provides social context for learning and makes collaborative learning possible (Liu \& Tsai, 2008). Previous studies mentioned that online asynchronous learning community has been the most adopted environment of interaction in CMC due to the advantages associated with it (Lucas et al., 2014; Yap \& Chia, 2010). Learners have opportunities to reflect, think, share their own experience with peers and search for new information in this environment (Anderson \& Dron, 2011; De Wever et al., 2006; Lee, 2012; Pena-Sheff \& Nichollas, 2004). Educators should design online courses to generate productive student-student interactions through content- and task-oriented discussions (Kim \& Bateman, 2010).

Hence, research on knowledge building depends on the application of interaction analysis 
models that aim to assess the quality of online asynchronous postings (Lucas, Gunwardena, \& Moreira, 2014). According to De Wever et al. (2006), interaction analysis in online asynchronous environment depends only on quantitative data, including the number of messages posted by the students, number of logs by each student and the length of each post. However, quantitative studies are limited to evaluate the quality of the learning process in the online community. As a result, researchers started espousing qualitative approach such as content analysis of asynchronous messages (Lucas, Gunwardena, \& Moreira, 2014).

\subsection{Research Questions}

In this study, we tried to explore how students build their knowledge collaboratively in the online learning community. To answer this question, we formulate two research questions:

1) What are the types of discussion students engage in the online discussion forum?

2) What are the types of interaction among the students in the online discussion forum?

\section{Methods}

This study analyzes the weekly postings which were online messages posted on an asynchronous online learning community. The weekly postings were requirements for an online course. This study focuses on the analysis of the types of interaction and the types of discussion in an online learning community.

\subsection{Context of Study}

This case study was conducted in an online graduate course. The course continued for sixteen weeks. Using asynchronous online discussion the instructor gave a prompt, students responded with an initial post and later other students commented on, challenged, or questioned their peers. Students learned diverse cases and provided solutions or made comments on each-other's postings. Seventeen graduate students participated in this course. The instructor divided the participants into three groups in order to discuss three cases about instructional design. Each group was composed of 5-6 students. Each participant was required to make two postings weekly; they could post new ideas or could comment on someone else idea. Students were allowed to comment on the postings of their respective group and could not access other group's postings.

Data was collected from online discussion forums. Students used an online asynchronous discussion tool provided by a common learning management system (LMS), Canvas. The third researcher taught the course and provided the data after hiding the identities of the participants. The study was approved by the University Institutional Review Board (\#1502734776) and did not involve any monetary compensation.

\subsection{Coding Scheme}

Various well known models (e.g., Hara, Bonk, \& Angeli, 2000; Henri, 1992; Gunawardena et al., 1997; Newman, Webb, \& Cochrane, 1995; Pena-Shaff, 2001) provided initial guidelines for the coding scheme as they shed light on types of interaction and knowledge building process in an online community. The researchers developed initial categories and indicators 
applied to the data, and then modified it to provide more concise and coherent categories and indicators. The data analysis consisted of two domains: cognitive domain and social domain. The researcher mainly used cognitive domain in this study in order to analyze types of interaction that ultimately implied to knowledge building.

There are three layers in the coding scheme. The first layer tells if responders agree or disagree with the initial message. The second layer reveals if the response has a reason or not for agreement. Finally, the third layer discloses what types of reason the response has. Since the aim of this study is to reveal types of interaction that contribute to knowledge building, the researchers focused on responses on initial messages. The researchers have divided participants' messages into two groups: monologues and interactive messages. Only interactive messages with agreement or disagreement provided by rationale were considered in the analysis stage as they provided answers to the research questions. Furthermore, agreement or disagreement without reason and social domain were not considered as they did not contribute to foster interaction or discussion in the virtual environment. In addition, monologue messages (initial messages that did not get any reply from other students) were not coded because there was no interaction. Table 1 shows the three layers system and indicates the types of interaction that imply knowledge building process. The table also provides description of the indicators with examples of the codes.

\subsection{Coding Procedure}

In the beginning the coders met in order to identify the basic procedure for segmentation of the messages and then coded them. Discussion transcripts from Case I, Group I were used for practicing and training to master the coding scheme. Following the practice session, the coders worked independently in coding the units of analysis. The following steps were taken to reduce any ambiguity and bias in the coding process: (a) Practice coding on Group I and discussion were to emphasize procedures for the coding and the criteria established for each indicator (see Table 1), (b) Separation of the unit of analysis of the coding was discussed between the coders to remove any error in the unit of data to code and reduce the overlap between the indicators. Based on the idea of the sentence, each individual message was broken into sentences and coded according to the coding scheme in order to understand the interaction among students. 
Table 1 . The coding scheme

\begin{tabular}{|c|c|c|c|c|c|c|}
\hline Layer 1 & Layer 2 & Layer 3 & Code & Indicators & Modifiers of Code & Example \\
\hline \multirow{9}{*}{ Agree } & $\begin{array}{l}\text { Without } \\
\text { Reason }\end{array}$ & & AWR & & $\begin{array}{l}\text { Agreement without a } \\
\text { rational reason, we will not } \\
\text { consider it as a knowledge } \\
\text { building }\end{array}$ & $\begin{array}{l}\text { I agree that everyone needs to speak } \\
\text { up who has gained expertise. }\end{array}$ \\
\hline & \multirow{8}{*}{ Reason } & \multirow{2}{*}{$\begin{array}{l}\text { Assertion/ } \\
\text { claim }\end{array}$} & \multirow[t]{2}{*}{ ARA } & Assertion & $\begin{array}{l}\text { Agreement with firm } \\
\text { acclimation, impose one's } \\
\text { opinion with authority. }\end{array}$ & $\begin{array}{l}\text { One of the roles of a team lead is to } \\
\text { put a structure in place so that } \\
\text { all-important issues are heard and } \\
\text { each voice contributes. }\end{array}$ \\
\hline & & & & Claim & $\begin{array}{l}\text { Agreement with a conscious } \\
\text { prediction, an authoritative } \\
\text { conclusion. }\end{array}$ & $\begin{array}{l}\text { That is exactly why I suggested that } \\
\text { there first thing to do get on track is } \\
\text { to meet with him }\end{array}$ \\
\hline & & \multirow{4}{*}{$\begin{array}{l}\text { Additional } \\
\text { Information }\end{array}$} & \multirow{4}{*}{ ARI } & New Idea & $\begin{array}{l}\text { Agreement with new } \\
\text { information, provide } \\
\text { additional information. }\end{array}$ & $\begin{array}{l}\text { In addition, the students determined } \\
\text { that there was not a lot of time to } \\
\text { play the game due to teachers } \\
\text { having to move onto the next unit. } \\
\text { They never discussed how this } \\
\text { would affect playing time of the } \\
\text { game. }\end{array}$ \\
\hline & & & & Opinion & $\begin{array}{l}\text { Agreement with one's } \\
\text { thought, self-belief. }\end{array}$ & $\begin{array}{l}\text { I also agree that there were no } \\
\text { learning objectives. Learning } \\
\text { objectives, in this case, would have } \\
\text { more clearly guided the research } \\
\text { gathered. }\end{array}$ \\
\hline & & & & Suggestion & $\begin{array}{l}\text { Agreement with suggestive } \\
\text { comments, further } \\
\text { information }\end{array}$ & $\begin{array}{l}\text { They would be creating a video } \\
\text { game that would last just a few } \\
\text { hours. }\end{array}$ \\
\hline & & & & $\begin{array}{l}\text { Sharing } \\
\text { experience }\end{array}$ & $\begin{array}{l}\text { Agreement with one's own } \\
\text { personal experiences }\end{array}$ & $\begin{array}{l}\text { I worked for a wonderful director } \\
\text { early in my career who was adept at } \\
\text { reminding our team that we could } \\
\text { not fall so in love with our project } \\
\text { that we lost sight of the purpose. }\end{array}$ \\
\hline & & \multirow{2}{*}{$\begin{array}{l}\text { Request } \\
\text { Clarification/ } \\
\text { information }\end{array}$} & \multirow{2}{*}{ ARC } & Clarification & $\begin{array}{l}\text { Agreement with } \\
\text { questioning for clear } \\
\text { concept, asking more } \\
\text { questions }\end{array}$ & $\begin{array}{l}\text { Do you think it would have been } \\
\text { more helpful to include one sooner, } \\
\text { in order to make the task clearer? }\end{array}$ \\
\hline & & & & Information & $\begin{array}{l}\text { Agreement with asking } \\
\text { about more information } \\
\text { through using questions }\end{array}$ & $\begin{array}{l}\text { Are they based on the principal's } \\
\text { interest in playing baseball, and he } \\
\text { is attempting to connect this interest } \\
\text { to an educational standard ...? }\end{array}$ \\
\hline \multirow[b]{2}{*}{ Disagree } & $\begin{array}{l}\text { Without } \\
\text { Reason }\end{array}$ & & DWR & & $\begin{array}{l}\text { Disagreement without } \\
\text { providing rational reason; } \\
\text { we will not consider it as } \\
\text { knowledge acquisition }\end{array}$ & I disagree with your statement. \\
\hline & Reason & $\begin{array}{l}\text { Alternative } \\
\text { claim/idea }\end{array}$ & DRA & $\begin{array}{l}\text { Alternative } \\
\text { Idea }\end{array}$ & $\begin{array}{l}\text { Disagreement with } \\
\text { providing new ideas to } \\
\text { support one's attitude, } \\
\text { conflictive opinions. }\end{array}$ & $\begin{array}{l}\text { However, I did not see a problem } \\
\text { with the team members varied } \\
\text { backgrounds. I think that if you had } \\
\text { a group of like individuals in skill } \\
\text { and interests, the end result would } \\
\text { be a rather limited product. }\end{array}$ \\
\hline
\end{tabular}




\begin{tabular}{|c|c|c|c|c|c|}
\hline & $\begin{array}{l}\text { Additional } \\
\text { Information }\end{array}$ & DRI & $\begin{array}{l}\text { New } \\
\text { suggestion }\end{array}$ & $\begin{array}{l}\text { Disagreement with } \\
\text { providing a suggestion, } \\
\text { proposal }\end{array}$ & $\begin{array}{l}\text { They may have wanted to add team } \\
\text { members, including additional } \\
\text { educators who work with the at-risk } \\
\text { population and someone more } \\
\text { familiar with educational gaming. }\end{array}$ \\
\hline & $\begin{array}{l}\text { Request } \\
\text { Clarification/ } \\
\text { information }\end{array}$ & DRC & $\begin{array}{l}\text { Asking new } \\
\text { information }\end{array}$ & $\begin{array}{l}\text { Disagreement with asking } \\
\text { about more information or } \\
\text { clarification }\end{array}$ & $\begin{array}{l}\text { It reminds me of Daniel Goleman } \\
\text { and his book on Emotional } \\
\text { Intelligence - There must have } \\
\text { been a good bit of research done } \\
\text { on this? }\end{array}$ \\
\hline Others & & OS & $\begin{array}{l}\text { Social } \\
\text { (appreciate, } \\
\text { apologize, } \\
\text { greeting) }\end{array}$ & $\begin{array}{l}\text { The sentences not located in } \\
\text { the agreement or } \\
\text { disagreement; they use } \\
\text { sentences for greeting, or } \\
\text { appreciating others work. } \\
\text { We will not consider these } \\
\text { sentences as knowledge } \\
\text { building }\end{array}$ & Thank you for sharing! \\
\hline
\end{tabular}

\subsection{Data Analysis}

In this case study, the researchers used both qualitative and quantitative approaches to describe and analyze the types of interaction in the online learning community. The quantitative data includes the total number of interactive messages posted by each group. The qualitative data was composed of content analysis of the messages to evaluate the quality and processes of learning in the online environment.

Data analysis divided into two phases - the first phase was group level and the second phase was the individual level. The researchers have calculated the percentages for each category and compared it within the groups for all cases in order to understand the types of interaction the students were engaged in the groups. Additionally, the researchers have investigated the interaction between participants in each group through the frequency of postings.

De Wever et al. (2006) mention that inter-rater reliability is a critical concern in relation to content analysis. In order to establish consistency and to achieve higher reliability, the coders independently analyzed a pilot set of the first case for the first group (Group I). The researchers coded all the messages for data analysis to validate the coding procedures; the coders discussed and negotiated in terms of the difference in coding to attain agreement. The negotiation between the coders started after finishing each group in order to resolve differences among them. For all cases, the agreement between the coders on group I is $92 \%$, respectively $95.7 \%$ on group II and $91.4 \%$ on group III. 
Table 2. Frequency of the indicators for individual student

\begin{tabular}{|l|l|l|l|l|l|l|}
\hline \multirow{2}{*}{ Member } & \multicolumn{3}{|c|}{ Agree } & \multicolumn{3}{c|}{ Disagree } \\
\cline { 2 - 7 } & ARA & ARI & ARC & DRA & DRI & DRC \\
\hline Student 1 & 12 & 24 & 5 & 3 & 3 & 0 \\
\hline Student 2* & 7 & 17 & 6 & 4 & 13 & 1 \\
\hline Student 3 & 2 & 13 & 0 & 1 & 3 & 0 \\
\hline Student 4 & 4 & 11 & 8 & 4 & 2 & 0 \\
\hline Student 5 & 13 & 16 & 3 & 0 & 0 & 0 \\
\hline Student 6 & 14 & 18 & 8 & 2 & 3 & 1 \\
\hline Student 7 & 13 & 31 & 8 & 2 & 2 & 3 \\
\hline Student 8 & 10 & 28 & 5 & 3 & 1 & 0 \\
\hline Student 9 & 3 & 5 & 2 & 1 & 0 & 0 \\
\hline Student $10 *$ & 5 & 18 & 2 & 1 & 6 & 2 \\
\hline Student $11 *$ & 7 & 25 & 3 & 2 & 7 & 0 \\
\hline Student 12 & 10 & 15 & 1 & 0 & 5 & 0 \\
\hline Student 13 & 6 & 19 & 2 & 1 & 1 & 0 \\
\hline Student 14 & 3 & 20 & 2 & 2 & 1 & 0 \\
\hline Student 15 & 3 & 16 & 2 & 0 & 0 & 0 \\
\hline Student 16 & 10 & 19 & 0 & 0 & 4 & 2 \\
\hline Student 17 & 0 & 13 & 0 & 0 & 5 & 0 \\
\hline
\end{tabular}

Note. ARA - Agree with assertion, ARI - Agree with additional information, ARC - Agree with request clarification; DRA - Disagree with assertion, DRI - Disagree with additional information, DRC - Disagree with request clarification.

*Students have the most disagreement with others.

\section{Results}

Findings Research Question \# 1: What are the types of discussion students engage in the online discussion forum?

On an average throughout the cases, some students contributed a little over the two required messages per case (two postings weekly). Messages coded as assertion/claim (19.8\%) and additional information (48.1\%) when students agreed with their peers was accounted for the highest frequencies of cognitive dimension in the cases. In the same category, messages 
coded as request clarification/information was accounted for 9.7\%. The non-cognitive category (AWR. DWR, OS) accounted $7.1 \%$ of total messages.

In the discussion forum, students expressed mainly agreements with their colleagues' initial posts (See Table 2). The agreement was $77.6 \%$ whereas the disagreement was only $14.8 \%$. In an average, each student made $5.8 \%$ of the disagreement statements. However, three students made $38.1 \%$ of the disagreement statements.

Table 2 describes the frequency of each indicator for each participant. The results reveal three particular students made the most disagreement messages (36 disagreement postings out of 92 , which is about $39 \%$ ) which would require further investigation in order to form overall understanding of types of discussion in an online discussion forum. These three individuals (student $\# 02$, student $\# 10$, and student \#11) continued to provide disagreements across the cases. They disclosed disagreements not only with an individual's initial post, but also with re-posts in the entire discussion. The highest disagreement indicator was disagree with adding additional information. The percentage of this indicator was $53.3 \%$ (which was more than half of total disagreement messages). Whereas disagreement with providing alternative idea was $25 \%$ and the last indicator in this group disagree with requesting additional clarification was $21.7 \%$.

The researchers also noticed that sometimes participants who posted initial messages agreed with their colleagues' disagreement statements; however, at times they imposed disagreements with their colleagues' disagreement statements. As we followed the three individuals closely, we noticed that they refuted their classmates' opinions more so than others. For example, Student \#11 disagreed with student \#14's initial post by providing additional information about establishing trust and encouraging comfort in an online learning environment in comparison with face-to-face learning environment. Whereas student \#14 replied back to agree with student \#11's suggestions by providing additional information, but highlighted that trust and comfortability could appear as personal characteristics. After such student \#11 replied to agree with student \#14 and requested additional clarification.

Findings Research Question \# 2: What are the types of interaction among the students in the online discussion forum?

In Table 3, five interaction patterns were identified for this study that was adapted from Fung's study (2004) with a slight modification. The definitions of these patterns and their frequencies are shown below. In several initial postings, there was no response to a student's message or only one student responded and the discussion then stopped, which was 42 messages or about $7 \%$ of total messages. However, there were many messages where two or more students had paired dialogues and continued with a cyclic discussion (228 messages or $36.4 \%$ ). The most occurred interaction pattern was branching interaction, which was close to half of the total interaction (279 messages or about $45 \%$ of total messages). Therefore, together desired interactions (cyclic, branching, and complex) were accounted for $93.3 \%$. 
Table 3. Interaction patterns

\begin{tabular}{|l|l|l|l|}
\hline Pattern & Explanation & $\begin{array}{l}\text { Number of } \\
\text { messages }\end{array}$ & Percentages \\
\hline Monologue & $\begin{array}{l}\text { One message posted by a student without any } \\
\text { response }\end{array}$ & 18 & $2.9 \%$ \\
\hline Single response & $\begin{array}{l}\text { One message posted by a student with one } \\
\text { response in one way }\end{array}$ & 24 & $3.8 \%$ \\
\hline Cyclic interaction & $\begin{array}{l}\text { A dialogue set up between initiator and one or } \\
\text { two respondents in two ways }\end{array}$ & 228 & $36.4 \%$ \\
\hline Branching interaction & $\begin{array}{l}\text { One message posted by a student with two or } \\
\text { more response messages at the same time }\end{array}$ & 279 & $44.6 \%$ \\
\hline Complex interaction & $\begin{array}{l}\text { This type of interaction contains all the above } \\
\text { interaction in the same time. }\end{array}$ & 77 & $12.3 \%$ \\
\hline
\end{tabular}

Case II and III had more complex interactions than case I. In general, the content of these messages were responses of previous messages. According to Fung (2004), complex interaction could be considered as meaningful interactive discussion. Below is an example of a complex interaction among several students:

Initiator (Student 14): One environmental input that helped the face-to-face M2M program was the bringing together of dozens of like-minded people who were concerned about their future. This was an example of motivational management that increased interest.

\begin{tabular}{|l|l|l|}
\hline Reply & To & Example \\
\hline Student 11 & Student 14 & $\begin{array}{l}\text { I would say, though, that I'm not sure I'm in complete agreement about } \\
\text { your feelings toward online communities. }\end{array}$ \\
\hline Student 14 & Student 11 & I think the ability to open up online is a personal matter, \\
\hline Student 7 & Student 11 & $\begin{array}{l}\text { Student 11, do you think the effectiveness of some online communities } \\
\text { has to do with expectations? }\end{array}$ \\
\hline Student 11 & Student 7 & $\begin{array}{l}\text { I know that my sister, who recently lost two pregnancies, has received an } \\
\text { inordinate amount of support from her online groups - and to be quite } \\
\text { honest, probably even more so than from the rest of us. }\end{array}$ \\
\hline Student 17 & Student 11 & $\begin{array}{l}\text { I agree with you on this Student 11 - I think that like-minded groups } \\
\text { online have proven to help certain people. }\end{array}$ \\
\hline Student 11 & Student 14 & $\begin{array}{l}\text { What do you feel that the M2M online version would need to do in order } \\
\text { to establish trust, affiliation, and cooperative interaction? }\end{array}$ \\
\hline
\end{tabular}


Isolated
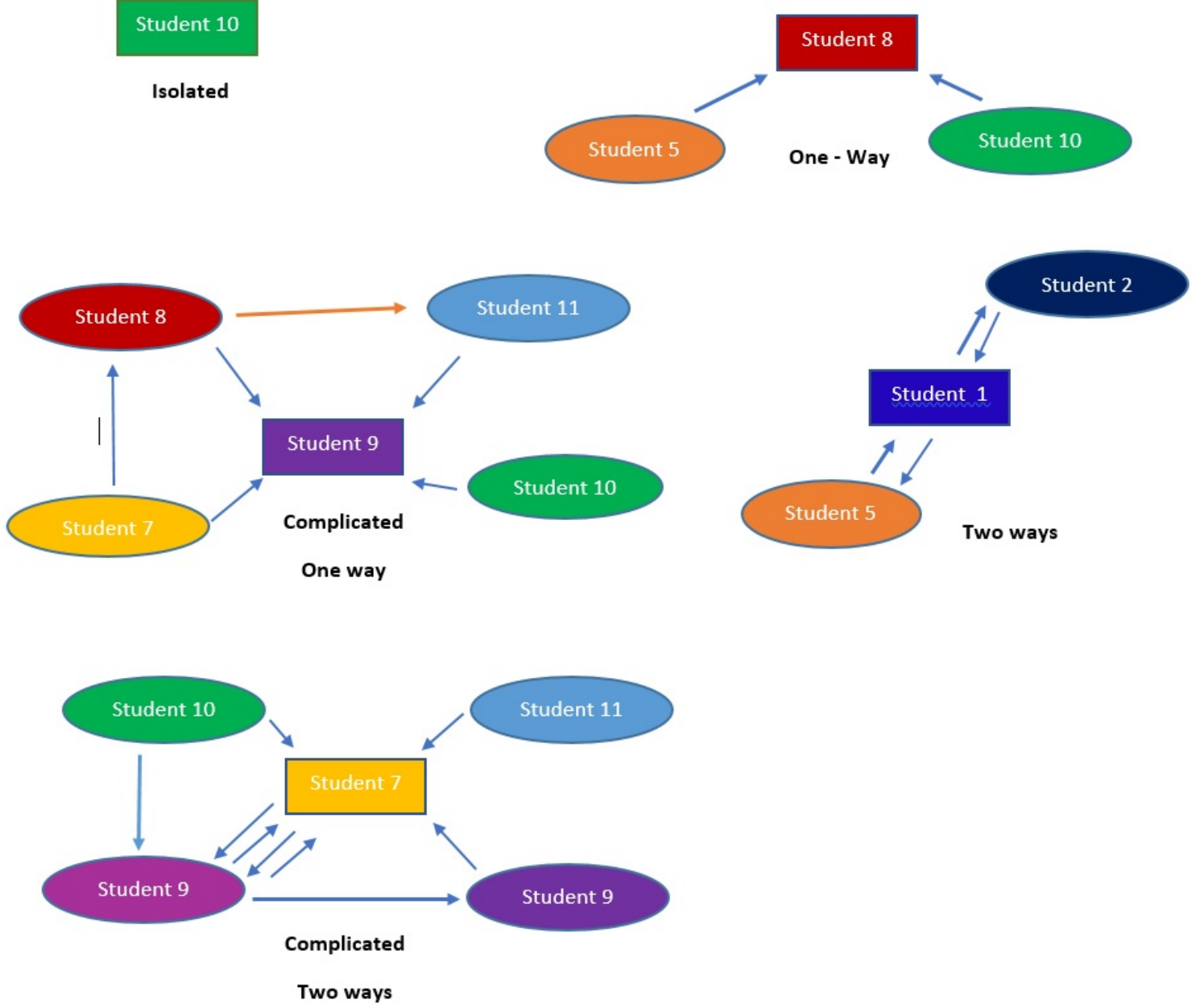

Figure 1. Illustration of the interaction pattern among the participants in the online learning community

\section{Discussion}

In most cases students posted just two messages per week in order to satisfy the minimum course requirement. However, there was clear evidence suggesting that students exhibited more cyclic, branching and complex interactions (which accumulated to $93.3 \%$ of total interactions). In addition, the researchers noticed that the disagreements among the participants in an online discussion created an encouraging and conducive environment to continue constructive debate among the participants. In several postings, we found a complex interaction pattern between the participants (the initiator and participants who disagreed with the post).

In this study, we used both the number of individual messages posted on online discussion forum in each group to understand how students participate in the online discussion forums and types of interaction between them. The analysis of students' messages and interaction patterns revealed the group's dynamics of online discussion among the students. Participation and interaction can be understood in several ways. Such methods include reading someone's messages, posting one's own messages, responding to other's opinions, and sharing one's 
own information with others (Garrison, Anderson, \& Archer, 2001; Yap \& Chia, 2010). However, the result of the first case analysis showed it was possible to obtain higher cognitive dimension of knowledge building within the structure of discussion. The results revealed that dividing students into groups affected students' participation in the online discussion (Kim, 2013). The findings of the study indicate that active participation in interaction does not simply occur, but must be purposefully incorporated into the course (Berge, 1999). The results in this study supported previous research that CMC provides interactive and negotiation environment which could be potentially helpful for enhancing students' participation and engagement (Zheng \& Warschauer, 2015; Lee, 2012).

\subsection{Limitations and Further Research}

Despite the usefulness of the study results, there have several limitations. The generalization of the study is controlled by the context of small number of graduate students using online environment. Data analysis is based only on the content of the postings. To better understand the student learning process, further research should involve additional factors that affect knowledge building in online communities such as the academic performance and intervene factors design. Further research should explore the effect of instructor's feedback on the process of knowledge building.

\section{Conclusion}

The purpose of the study is to identify the discussion patterns and types of interaction in the process knowledge acquisition among graduate students in an online class. The findings of this study indicate that computer mediated communication (CMC) has the ability to enhance knowledge building and it has a positive potential to increase interaction and participation among students. The study findings confirmed the effectiveness of asynchronous online environment in supporting online learning community. Participants were engaged in social interaction to build their knowledge. This study recommended two-ways interaction for achieving sustainable discussion and promoting higher level of knowledge construction.

\section{References}

Allen, I. E., \& Seaman, J. (2015). Grade Level. Tracking Online Education in the United States. Babson Survey Research Group and Quahog Research Group, LLC.

Anderson, T., \& Dron, J. (2010). Three generations of distance education pedagogy. The International Review of research in Open and Distributed Learning, 12(3), 80-97. https://doi.org/10.19173/irrodl.v12i3.890

Balaji, M. S., \& Chakrabarti, D. (2010). Student interactions in online discussion forum: Empirical research from 'media richness theory' perspective. Journal of Interactive Online Learning, 9(1), 1-22.

Berge, Z. L. (1999). Interaction in post-secondary web-based learning. Educational Technology (Vol. 39, pp. 5-11). Saddle Brook, NJ, USA.

Brook, C., \& Oliver, R. (2003). Online learning communities: Investigating a design 
framework. Australian Journal of Educational Technology, 19(2), 139-160. https://doi.org/ 10.14742/ajet. 1708

Chai, C. S., \& Khine, M. S. (2006). An analysis of interaction and participation patterns in online community. Educational Technology \& Society, 9(1), 250-261.

Choo, L. P., Kaur, G., Fook, C. Y., \& Yong, T. C. (2014). Patterns of Interaction among ESL Students During Online Collaboration. Procedia-Social and Behavioral Sciences, 123, 307-314. https://doi.org/10.1016/j.sbspro.2014.01.1428

De Wever, B., Schellens, T., Valcke, M., \& Van Keer, H. (2006). Content analysis schemes to analyze transcripts of online asynchronous discussion groups: A review. Computers \& Education, 46(1), 6-28. https://doi.org/10.1016/j.compedu.2005.04.005

Fung, Y. Y. (2004). Collaborative online learning: Interaction patterns and limiting factors. Open Learning: The Journal of Open, Distance and e-Learning, 19(2), 135-149. https://doi.org/10.1080/0268051042000224743

Garrison, D. R., Anderson, T., \& Archer, W. (2001). Critical thinking, cognitive presence, and computer conferencing in distance education. American Journal of Distance Education, 15(1), 7-23. https://doi.org/10.1080/08923640109527071

Gray, C., \& Smyth, K. (2012). Collaboration Creation: Lessons Learned from Establishing an Online Professional Learning Community. Electronic Journal of e-Learning, 10(1), 60-75.

Gunawardena, C. N., Lowe, C., \& Anderson, T. (1997). Analysis of a global online debate and the development of an interaction analysis model for examining social construction of knowledge in computer conferencing. Journal of Educational Computing Research, 17(4), 397-431. https://doi.org/10.2190/7MQV-X9UJ-C7Q3-NRAG

Hara, N., Bonk, C. J., \& Angeli, C. (2000). Content analysis of online discussion in an applied educational psychology course. Instructional Science, 28(2), 115-152. https://doi.org/ 10.1023/A:1003764722829

Henri, F. (1992). Computer conferencing and content analysis. In A. R. Kaye (Ed.), Collaborative learning through computer conferencing. The Najadan Papers (pp. 117-136). London: Springer-Verlag. https://doi.org/10.1007/978-3-642-77684-7_8

Kim, H. K., \& Bateman, B. (2010). Student participation patterns in online discussion: Incorporating constructivist discussion into online courses. International Journal on E-Learning, 9(1), 79-98.

Kim, J. (2013). Influence of group size on students' participation in online discussion forums. Computers \& Education, 62, 123-129. https://doi.org/10.106/j.compedu.2012.10.025

Lee, J. (2012). Patterns of Interaction and Participation in a Large Online Course: Strategies for Fostering Sustainable Discussion. Educational Technology \& Society, 15(1), 260-272.

Liu, C. C., \& Tsai, C. C. (2008). An analysis of peer interaction patterns as discoursed by on-line small group problem-solving activity. Computers \& Education, 50(3), 627-639. 
https://doi.org/10.1016/j.compedu.2006.07.002

Loncar, M., Barrett, N. E., \& Liu, G. Z. (2014). Towards the refinement of forum and asynchronous online discussion in educational contexts worldwide: Trends and investigative approaches within a dominant research paradigm. Computers \& Education, 73, 93-110. https://doi.org/10.1016/j.compedu.2013.12.007

Lucas, M., Gunawardena, C., \& Moreira, A. (2014). Assessing social construction of knowledge online: A critique of the interaction analysis model. Computers in Human Behavior, 30, 574-582. https://doi.org/10.1016/j.chb.2013.07.050

Müller, T. (2008). Persistence of women in online degree-completion programs. The International Review of Research in Open and Distributed Learning, 9(2). https://doi.org/10.19173/irrodl.v9i2.455

Newman, D. R., Johnson, C., Webb, B., \& Cochrane, C. (1997). Evaluating the quality of learning in computer supported cooperative learning. Journal of the American Society of Information Science, 48, 484-495. https://doi.org/10.1002/(SICI)1097-4571(199706)48:6\%3 C484::AID-ASI2\%3E3.0.CO;2-Q

Pena-Shaff, J. B., \& Nicholls, C. (2004). Analyzing student interactions and meaning construction in computer bulletin board discussions. Computers \& Education, 42(3), 243-265. https://doi.org/10.1016/j.compedu.2003.08.003

Rodriguez, M. A. (2014). Content Analysis as a Method to Assess Online Discussions for Learning. SAGE Open, 4(4). https://doi.org/10.1177/2158244014559019

Rourke, L., Anderson, T., Garrison, D. R., \& Archer, W. (2001). Methodological issues in the content analysis of computer conference transcripts. International Journal of Artificial Intelligence in Education, 12, 8-22.

Schellens, T., \& Valcke, M. (2006). Fostering knowledge construction in university students through asynchronous discussion groups. Computer \& Education, 46(4), 349-370. https://doi.org/10.1016/j.compedu.2004.07.010

Schindler, L., \& Burkholder, G. J. (2014). Instructional design and facilitation approaches that promote critical thinking in asynchronous online discussions: A review of the literature. Higher Learning Research Communications, 4(4), 11-29. https://doi.org/10.18870/ hlrc.v4i4.222

Sher, A. (2009). Assessing the relationship of student-instructor and student-student interaction to student learning and satisfaction in Web-based Online Learning Environment. Journal of Interactive Online Learning, 8(2), 102-120.

Shu-Hui Hsieh, C., \& Smith, R. A. (2008). Effectiveness of Personal Interaction in a Learner-Centered Paradigm Distance Education Class Based on Student Satisfaction. Journal of Research on Technology in Education, 40(4), 407-426. https://doi.org/10.1080/15391523. 2008.10782514 


\section{Macrothink}

Soon, L., \& Fraser, C. (2011). Knowledge sharing and knowledge exchange in distance education online group work. International Journal of Information and Education Technology, 1(2), 156. https://doi.org/10.7763/IJIET.2011.V1.26

Swan, K. (2005). A constructivist model for thinking about learning online. In J. Bourne \& J. C. Moore (Eds.), Elements of quality online education: Engaging communities (pp. 13-30). Needham, MA: Sloan-C.

Vygotsky, L. (1978). Interaction between learning and development. Readings on the Development of Children, 23(3), 34-41.

Wei, H. C., Peng, H., \& Chou, C. (2015). Can more interactivity improve learning achievement in an online course? Effects of college students' perception and actual use of a course-management system on their learning achievement. Computers \& Education, 83, 10-21. https://doi.org/10.1016/j.compedu.2014.12.013

Yap, K. C., \& Chia, K. P. (2010). Knowledge construction and misconstruction: A case study approach in asynchronous discussion using Knowledge Construction-Message Map (KCMM) and Knowledge Construction-Message Graph (KCMG). Computers \& Education, 55(4), 1589-1613. https://doi.org/10.1016/j.compedu.2010.07.002

Yuan, J., \& Kim, C. (2014). Guidelines for facilitating the development of learning communities in online courses. Journal of Computer Assisted Learning, 30, 220-232. https://doi.org/10.1111/jcal.12042

Zheng, B., \& Warschauer, M. (2015). Participation, interaction, and academic achievement in an online discussion environment. Computers \& Education, 84, 78-89. https://doi.org/ 10.1016/j.compedu.2015.01.008

\section{Copyright Disclaimer}

Copyright for this article is retained by the author(s), with first publication rights granted to the journal.

This is an open-access article distributed under the terms and conditions of the Creative Commons Attribution license (http://creativecommons.org/licenses/by/3.0/). 